until night, in the preparation and the distribution of life-giving food to the plant or tree.

As the leaf nears the end of Summer, and its alloted span, there are many factors which contribute to its maturity and color change. The days become shorter with less and weaker light. The nights become correspondingly longer and cooler. Water with its minerals cease to run up the pipelines with usual agility. The flow thickens and becomes slower. The air and soil are drier and there is a gradual slowing down of supplies to the leaf. The tiny veinlets become clogged with waste and the deposits of unused mineral. Factory operations become tired and sluggish and the processing tapers off toward the inevitable end. It is the normal ending of a life cycle; the natural termination of the work, the purpose and life of the leaf.

Then come the still colder days and nights to hasten the end. The demise is quickened by an extremely cold night. Leaf life would cease anyway but Nature with her sudden cold gives the kindly aid to what might otherwise be a lingering death. The green chlorophyll disappears entirely, leaving exposed some of the unused sugars and pigments to glow in their own original colors of red, yellow, and purple. Chemical changes are brought about by a death pigment called anthocynin. The final waste substances and leftover pigments are capables of a thousand shades and hues. The leaf which has worked all summer must die like all living things and in dying is transfigured. The painted woods bear testimony to the completion of one more cycle. The passing is the fulfillment of a purpose-the nourishment and life of the tree. What a pity it is that all living things do not, in their departure, become transfigured with the beauty and glory of the autumn leaf.

The passing of an autumn leaf takes place where Jack Frost is unknown and rarely if ever appears. That the transfiguration is most beautiful in the northern climates is due perhaps to the colder drier air: the climate itself; the flora characteristics and many factors of plant ecology. In places where there is an early frost of heavy proportions there is little autumnal beauty for the very touch of Jack Frost's destroying power browns, shrivels and curls the dying leaf. It is his wand that throws down the leaf before it has fulfilled its final function.

How very fortunatet are those who live in the land where abound the Sugar Maples. Maples are without peer in their contribution to the brilliancy and range of color. One of our best known and much admired botanists and naturalists-Donald Culross Peattie, in his new book, "A NATURAL HISTORY OF TREES," says, "The most magnificent display of color in all the kingdom of plants is in the autumnal foliage of the trees of North America. Over them all, over the clear light of the Aspens and Mountain Ash, over the leaping flame of Sumac and the hell-fire flickerings of poison ivy, over the war-paint of the many Oaks, rise the colors of one tree-the Sugar Maple-in the shout of one great army. Clearest yellow, richest crimson, tumultuous scarlet, or brilliant orange-the yellow pigments shining through the overpainting of red-the foliage of Sugar Maple outdoes and unifies the rest. It is like the mighty, matching melody that rides upon the crest of some symphonic weltering sea and, with its crying song, gives meaning to all the calculated dissonance of the orchestra." Anonymously submitted.

\section{A Pocket Hatchery}

From the Regina Leader Post

What a small boy has in his pockets has been the subject of many a story and poem, but this one is hard to beat.

The other day, David Fox, small scn of Rev. R. Fox and Mrs. Fox in Wadena, found a sparrow's egg lying on the sidewalk. Within a second it was inside David's pocket and he was off to play.

On his arrival home David put his hand in his pocket and was amazed to find a baby sparrow. The wonderfu: discovery was carefully bedded down in a dixie cup hung by string close to the kitchen stove and the tiny bird was soon chirping so loudly David named it "Chip." 